DOI: 10.31866/2617-2674.4.1.2021.235089

UDC 77.041.7:159.9

\title{
PSYCHOLOGICAL ASPECTS OF SOCIAL PHOTOGRAPHY
}

\section{Serhii Bordeniuk ${ }^{1 a}$, Viktoriia Byshovets ${ }^{2 a}$}

${ }^{1}$ Honored Art Worker of Ukraine, Professor of the Cinema and Television Arts Department; e-mail: BordenS2662@gmail.com, ORCID: 0000-0003-2561-1409

${ }^{2}$ Master's Student at the Television Journalism and Acting Department; e-mail: vibyshovets@gmail.com; ORCID:0000-0002-2320-9304

${ }^{a}$ Kyiv National University of Culture and Arts, Kyiv, Ukraine

\section{Keywords:}

photography;

psychology;

philosophy;

aspect;

perspective;

category

\begin{abstract}
The purpose of the research is to analyze the main features of social photography in the psychological aspect of the photographer. The research methodology is based on the application of a system-integrated approach to the review of this problem, within the framework of which a whole range of cultural, philosophical, psychological and professional qualities that affect viewers when viewing photographs is considered. The scientific novelty lies in the analysis of modern typological features and characteristics of social photography. The opinions of scientists from different times on issues of the psychological aspects of social photography were also systematized and generalized. Conclusions. We have analyzed the components of the psychological aspect of social photography. With the help of the analysis, the value of psychology in the work of the photographer specializing in the field of social photography has been established. Structural components that form a psychological aspect in the photo have been developed in detail. The factors that influence the rating of social photography have been summarized. The importance of the psychological aspects of social photography has been determined, since during the work at the same time the process of becoming the author himself, and his main task is to not just capture the environment but through his work to express feelings, emotions and thoughts.
\end{abstract}

For citation:

Bordeniuk, S. and Byshovets, V. (2021). Psychological aspects of social photography. Bulletin of Kyiv National University of Culture and Arts. Series in Audiovisual Arts and Production, 4(1), pp.78-83.

\section{Problem statement}

Social photography is a very interesting subject for discussion in the scientific community, because the practical component of social photography is dominant, and not all researchers undertake such research, especially in terms of 
scientific analysis of audiovisual, psychological and philosophical aspects of photography. But is necessary to try to master the scientific component of photography, and especially social photography, which is becoming very relevant in our time. Psychological aspects of social photography are almost not studied in the scientific literature, so we decided to focus our research on the psychology of photography.

\section{Recent research and publications analysis}

The topic of social photography is not sufficiently researched, but some scientists have analyzed photography from this point of view. The following scientific publications were used in the study: R. Barth (1997) described the philosophy of photography; S. Sontag (1998) analyzed the view of photography; A. Lapin (2003) revealed the concept of a photo; O. Mikhalkovich (1989) explored the poetics of photography.

The purpose of the article is to show the significant components of social photography in the psychological aspect; to analyze the main characteristics of social photography; to separate the main psychological aspects of social photography; to find out the problems of creation's perception and social photography perception.

\section{Main research material}

Photography, becoming the first technical factor of new media, revealed the communicative possibilities of visuality and perception. In the age of digital images, the perception of photographic images depends on the developed human ability to decode and interpret images, new abilities require new visual competencies.

As practice shows, the photo conveys the basic prerequisites of the one who observes everyone in different respects. Self-identification allows you to look at yourself from another angle. This is due to the latest technologies and special programs. They help to make adjustments to their "self" and correct what does not suit them.

During the work on the article, an empirical method was used to study the socially significant characteristics of social photography, as well as a complex analytical one to reveal and formulate the conceptual apparatus of research and study of issues.

Today, one of the most influential visual aids is the art of photography, which has a huge impact on people. Photography is used both to visualize information and to tell us about any event, without using verbal means.

Art researchers classify photography into three main areas: commercial, artistic, and technical, but there is a great variety of genres, each of which works according to its own internal laws.

Modern photography, in the network of globalization, informatization and computerization, has become the focus of theorists and practitioners, due to the ability of photography to create a new method of relation to reality through photographic images. Philosophical analysis of photography allows us to consider it as a social phenomenon that is closely linked to the complex world of human relations, images, technology and society, the development and change of all spheres of human life. In social philosophy and psychology, photography is becoming a means of thinking about our society, which provoked increased 
interest in photography in various fields of social sciences in various disciplines: art history, philosophy, psychology and sociology, anthropology and communication theorists.

Photography has contributed to the emergence of new visual practices and social relationships, which is impossible without psychological aspects, the consequences of which for society and man have not been fully understood yet.

Thanks to the rapid development and innovation processes in photographing, photographic equipment has become accessible and simpler, which promotes accessibility and, therefore, simplifying social relations, providing a greater immersion of people in the creative skill of the personality behaviour reality, which has become an integral part of the personality identification and its environments.

The photograph is the part of life reflection, although it is subjective. Most research on this topic has the notion that a photographer is a researcher. O. Lapin (1997, pp.119-120) called it "an invaluable gift of photography because, in the end, the photograph depicts not what the photographer invented, but what happened once in a lifetime, and the author only saw and managed to engrave". Photography has long been considered evidence of life. According to the photographer S. Zontag (1998, pp.89-92), a photo is "the most accurate depiction of the visual reality facts". Social photography demonstrates it best of all. This genre of photography has many names that demonstrate all the properties. For example, O. Lapin $(2003, p .67)$ believes that such a photograph is "reportage" because reportage is a means of shooting: "Reportage photography is a counterweight to staging, it categorically does not allow any organization, direction, production. It is a photograph that is made by an "invisible" photographer with an "invisible" camera".

Researchers often call social photography "photography of the moment" because it has its tendency to search for the beautiful, expressive and knows how to stop at the moment. You can also hear that this type is called a "detail photograph" - it shows a person as a detail at the moment. Therefore, it attracts the attention of both the creator and the average consumer. To take such a picture means to go beyond reality. The concept of "realistic photography" was proposed by the philosopher R. Bart, "genre photography" was named by V. Mikhalkovich (1989, pp.117-118). They called "genre" photography, which "depicts the states and actions of people." Now, this very concept has entered modern reality. Nevertheless, in our research, we rely on the term "social photography", because it best demonstrates and conveys all the properties.

The origin of this term came from the Latin "socialis", which means "sociable, social, public" (Ozhegov and Shvedova, 1999, pp.123-130). Consequently, the social - is "public, concerning the lives of people and their relationships in society" (Kuznetsov, 1998, p.567). Social photography is a photograph that best conveys the behaviour and relationships of others with certain people, details and personal processes, elements and processes that complement each other. The study shows a kind of photo, such as a "study of reality", because the photographer is looking for something that can interest in ordinary life without making any adjustments. The photographer himself finds what to photograph, the plot, the equipment and all this fills a certain meaning. 
What the viewer sees leads to the conclusion that a social photo that captures and creates something new around. Social photography gives an understanding of the life lived and felt by the author and the viewer, so it gives the opportunity to move to a completely new concept of meaning.

Unusual perception of the artist in combination with techniques make the pictures interesting and exciting, forming a subconscious connection between the picture and the author.

Success in any genre of photographer requires special psychological traits, especially in social photography, because it is necessary to capture the event or emotion that would best reflect the psychological portrait of reality seen from different angles.

In the practice of photography, the position of the observer is realized not only for others but also in relation to himself.

Self-identification through photography allows a person not only to see himself from the side but also to show himself another.

Photography as one of the genres of art requires not only the skills and mastery vision, their creative perception of the world. Psychology in photography is no less important than professional equipment. Without a creative search and approach, the ability to reach instantly to improvise, it is impossible to create your creative style that will be recognized by the audience. The psychological qualities of the photographer and his skill make it possible to realize a creative idea and get interesting photos.

One of the more interesting, in our opinion, features of social photography is its rich content, despite the external "vagueness" of what is happening on it.
The cognitive sphere of man in its structure and principles of operation is similar to modern computers. Like them, it perceives, stores and uses information coming from the outside world, information that appears to man in the form of knowledge about the world around him.

Psychological aspects of social photography are important because there is a process of becoming the author himself in the process of work at the same time, his main task is not just to engrave the environment but to express feelings, emotions and thoughts in his work.

\section{Conclusions}

Thus, in the age of digital technologies, the psychological component in social photography is intensifying. This an analysis of the photo image as a media component. The media essence is realized in its function as a communicative mediator. Image is an environment where the interpenetration of material and conceptual, individual and social is realized and simultaneously represented. In society, a photographic image is created and reproduced as socially significant components of the sensory and intellectual.

Thus, the main problems are the peculiarities of processing information that is perceived from the outside world. The acquisition of information is carried out through mental processes, such as perception of reality, way of thinking, experiencing emotions or the degree of imagination. It becomes clear that each person has their own personal, individual characteristics in the processing of information coming from the photographer and his work. 


\title{
REFERENCES
}

Bart, R., 1997. Camera lucida: Kommentarii k fotografii [Camera lucida: Commentary on photography]. Moscow: Ad Marginem.

Ivin, A.A. ed., 2004. Filosofiia: Entciklopedicheskii slovar [Philosophy: Encyclopedic Dictionary]. Moscow: Gardariki.

Kuznetcov, S.A. ed., 1998. Bolshoi tolkovyi slovar russkogo iazyka [Big explanatory dictionary of the Russian language]. St. Petersburg: Norint.

Lapin, A.I., 2003. Fotografiia kak ... [ Photography as ...]. Moscow: Izdatelstvo Moskovskogo universiteta.

Mikhalkovich, O.I. and Stigneev, V.T., 1989. Poetika foto [Poetics of photography]. Moscow: Iskusstvo.

Ozhegov, S.I. and Shvedova, N.lu., 1999. Tolkovyi slovar russkogo iazyka: 80000 slov i frazeologicheskikh vyrazhenii [Explanatory Dictionary of the Russian Language: 80,000 words and phraseological expressions]. Moscow: Azbukovnik.

Zontag, S., 1998. Vzgliad na fotografiiu [A Look at Photography]. In: Mir fotografii [The world of photography]. Moscow: Planeta.

\section{ПСИХОЛОГІЧНІ АСПЕКТИ СОЦІАЛЬНОЇ ФОТОГРАФІЇ}

\section{Сергій Борденюк ${ }^{1 a}$, Вікторія Бишовець ${ }^{2 a}$}

\author{
${ }^{1}$ заслужений діяч мистецтв України, професор кафедри кіно-, телемистецтва; \\ e-mail: BordenS2662@gmail.com; ORCID: 0000-0003-2561-1409 \\ ${ }^{2}$ магістрант кафедри кіно-, телемистецтва; \\ e-mail: vibyshovets@gmail.com; ORCID: 0000-0002-2320-9304 \\ Київський національний університет культури і мистецтв, Київ, Україна
}

\section{Анотація}

Мета дослідження - проаналізувати основні особливості соціальної фотографії у психологічному аспекті роботи фотографа. Методологія дослідження базується на застосуванні системнокомплексного підходу до огляду цієї проблеми, в межах якої розглядається цілий спектр культурологічних, філософських, психологічних та професійних аспектів, які впливають на глядачів під час перегляду фотографії. Наукова новизна полягає у аналізі сучасних типологічних особливостей та характеристик соціальної фотографії. Також було систематизовано і узагальнено думку науковців різних часів щодо психологічних аспектів соціальної фотографії. Висновки. У статті проаналізовано складові частини психологічного аспекту соціальної фотографії. За допомогою аналізу встановлено значення психології у роботі фотографа, що спеціалізується у царині соціальної фотографії. Детально опрацьовані структурні компоненти, які формують психологічний аспект у фотографії. Узагальнено чинники, які впливають на рейтинг соціальної фотографії. Визначено значущість психологічних аспектів соціальної фотографії, оскільки під час роботи одночасно відбувається процес становлення самого автора; а його головне завдання полягає у тому, щоб не просто закарбувати довкілля, а через свою роботу висловити почуття, емоції та думки.

Ключові слова: фотографія; психологія; філософія; аспект; ракурс; категорія 


\title{
ПСИХОЛОГИЧЕСКИЕ АСПЕКТЫ СОЦИАЛЬНОЙ ФОТОГРАФИИ
}

\author{
Сергей Борденюк ${ }^{1 a}$, Виктория Бышовец ${ }^{2 b}$ \\ 1 заслуженный деятель искусств Украины, профессор кафедры кино-, телеискусства; \\ e-mail: BordenS2662@gmail.com; ORCID: 0000-0003-2561-1409 \\ ${ }^{2}$ магистрант кафедры кино-, телеискусства; \\ e-mail: vibyshovets@gmail.com; ORCID: 0000-0002-2320-9304 \\ а Киевский национальный университет культуры и искусств, Киев, Украина
}

\begin{abstract}
Аннотация
Цель исследования - проанализировать основные особенности социальной фотографии в психологическом аспекте работы фотографа. Методология исследования базируется на применении системно-комплексного подхода к обзору этой проблемы, в рамках которой рассматривается целый спектр культурологических, философских, психологических и профессиональных качеств, влияющих на зрителей во время просмотра фотографии. Научная новизна заключается в анализе современных типологических особенностей и характеристик социальной фотографии. Также были систематизированы и обобщены мнения ученых разных времен в вопросах проблематики психологических аспектов социальной фотографии. Выводы. В статье проанализированы составляющие психологического аспекта социальной фотографии. С помощью анализа установлено значение психологии в работе фотографа, специализирующегося в области социальной фотографии. Детально проработаны структурные компоненты, которые формируют психологический аспект в фотографии. Обобщены факторы, которые влияют на рейтинг социальной фотографии. Определена значимость психологических аспектов социальной фотографии, поскольку во время работы одновременно происходит процесс становления самого автора; а его главная задача состоит в том, чтобы не просто запечатлеть окружающую среду, а через свою работу выразить чувства, эмоции и мысли.
\end{abstract}

Ключевые слова: фотография; психология; философия; аспект; ракурс; категория 